Original Article

Artigo Original

\title{
Desconforto do trato vocal em professores após atividade letiva
}

Keywords

Voice

Dysphonia

Faculty

Surveys and Questionnaires

Self-Assessment

Signs and Symptoms

Speech, Language and Hearing

Sciences

Descritores

Voz

Disfonia

Docentes

Inquéritos e Questionários Autoavaliação

Sinais e Sintomas

Fonoaudiologia

\begin{abstract}
Correspondence address:
Amanda Corrêa do Amaral

Rua Machado Bittencourt, 361/1001, Vila Mariana, São Paulo (SP), Brazil, CEP: 04044-001.

E-mail: amandafga14@gmail.com
\end{abstract}

Received: February 23, 2016

Accepted: July 13, 2016

\begin{abstract}
Purpose: To evaluate the vocal tract discomfort (VTD) reported by teachers, comparing their vocal self-assessment at three different times: before teaching, after four hours of teaching, and after eight hours of teaching. Methods: The study sample was composed of 50 teachers: 42 women and eight men. The participating teachers were divided into two groups according to the cutoff value of the Voice Symptom Scale (VoiSS): Vocal Risk Group (VRG) and Vocally Healthy Group (VHG). The List of Vocal Signs and Symptoms (LVSS) was used to identify the number of vocal symptoms in each group. The groups were evaluated at three specific moments (before (BT) and after four (4HT) and eight (8HT) hours of teaching) by means of the Vocal Tract Discomfort Scale (VTD scale) and vocal self-assessment. Results: The VRG presented more vocal signs and symptoms of the LVSS than the VHG (total: $\mathrm{VHG}=0.56 / \mathrm{VRG}=1.60, p<0.001$; work-related $\mathrm{VHG}=0.79 / \mathrm{VRG}=2.49, p<0.001$ ). The VHG did not report change in discomfort for both frequency $(p=1.132)$ and severity $(p=0.431)$ and showed better vocal self-assessment $(\mathrm{BT}=0.67 ; 4 \mathrm{HT}=0.96 ; 8 \mathrm{HT}=0.96, p=0.007)$. However, the VRG presented vocal tract discomfort after four and eight hours of teaching for both frequency $(\mathrm{BT}=1.60 ; 4 \mathrm{HT}=2.49 ; 8 \mathrm{HT}=2.95$, $p<0.001)$ and severity $(\mathrm{BT}=1.79 ; 4 \mathrm{HT}=2.52 ; 8 \mathrm{HT}=3.12, p<0.001)$ and worse voice self-assessment $(\mathrm{BT}=2.00$; $4 \mathrm{HT}=2.42 ; 8 \mathrm{HT}=3.00, p<0.001)$. Conclusion: Teachers at vocal risk present worse vocal self-assessment and increased vocal tract discomfort throughout the teaching working day.
\end{abstract}

\section{RESUMO}

Objetivo: Verificar o desconforto de trato vocal autorreferido por professores, comparando com a autoavaliação vocal, nos momentos de pré-jornada, pós-período de quatro horas e pós-período de oito horas de aula. Método: Participaram do estudo 50 professores, 42 mulheres e oito homens. O valor de corte da Escala de Sintomas Vocais - ESV dividiu os professores em Grupo Risco Vocal - GRV e Grupo Vocalmente Saudável - GVS e a Lista de Sinais e Sintomas Vocais - LSS foi utilizada para identificação da quantidade de sintomas vocais em cada grupo. Posteriormente, os grupos foram avaliados em três momentos (pré-jornada, pós-quatro horas e pós-oito horas) pela Escala de Desconforto do Trato Vocal - EDTV e autoavaliação vocal. Resultados: GRV apresentou mais sinais e sintomas vocais da LSS que o GVS (total: GS=0,56 / GRV=1,60, $<<0,001$; relacionados ao trabalho $\mathrm{GVS}=0,79 / \mathrm{GRV}=2,49, \mathrm{p}<0,001)$. O GVS não relatou mudança no desconforto, tanto para frequência $(\mathrm{p}=1,132)$ quanto para intensidade $(\mathrm{p}=0,431)$ e apresentou melhor autoavaliação vocal (pré $=0,67$; pós-quatro horas $=0,96$; pós-oito horas $=0,96 ; p=0,007$ ). Já o GRV apresentou mais desconforto no trato vocal após quatro e oito horas, tanto para frequência (pré $=1,60$; pós-quatro horas $=2,49$; pós-oito horas 2,$95 ; \mathrm{p}<0,001$ ) quanto para intensidade (pré $=1,79$; pós-quatro horas $=2,52$; pós-oito horas $=3,12$; $\mathrm{p}<0,001$ ), com pior autoavaliação vocal (pré $=2,00$; pós-quatro horas $=2,42$; pós-oito horas $=3,00 ; \mathrm{p}<0,001$ ). Conclusão: Professores com risco vocal têm pior autoavaliação de voz e maior desconforto do trato vocal, que aumenta durante o dia de atividade letiva.

Study carried out at Centro de Estudos da Voz - CEV - São Paulo (SP), Brazil, as a requirement for conclusion of the 'Curso de Especialização em Voz'. Presented at the 'XXIII Congresso Brasileiro' and 'IX Congresso Internacional de Fonoaudiologia': 14 to 16, october, 2015, Salvador (BA), Brazil.

${ }^{1}$ Centro de Estudos da Voz - CEV - São Paulo (SP), Brazil.

Financial support: nothing to declare.

Conflict of interests: nothing to declare. 


\section{INTRODUCTION}

The use of the voice is common in approximately one third of the working population and phonatory demand may vary according to the occupation ${ }^{(1)}$. In each profession, there may be a preferred type of voice, which involves effectiveness in communication and characteristics of the speakers and their occupations, generating variable vocal risk. Teachers are professionals who present a chance to develop moderate or severe voice problems, depending on their work environment and teaching hours ${ }^{(2)}$. Teachers can develop vocal alterations dependent on environmental, individual and emotional characteristics, which involve the individuals as a whole and the environment in which they are inserted ${ }^{(3)}$.

Teachers often speak for a long time, increase their vocal intensity, compete with environmental noise, have inadequate postures, strain the cervical muscles, and are not usually aware of vocal hygiene habits; they also normally face situations of anxiety, stress, and distress, as well as long working hours ${ }^{(4)}$. These factors contribute to the high prevalence of vocal symptoms and changes in this professional category ${ }^{(5)}$. Teachers with vocal complaints may have lower vocal resistance when compared with that of vocally healthy teachers ${ }^{(6)}$, which highlights the importance of identifying these vocal symptoms and changes.

The Voice Symptom Scale (VoiSS) ${ }^{(7,8)}$ is among the instruments used to investigate vocal symptoms and alterations. It comprises 30 items which explore three domains (subscales): impairment (15 items), emotional response (eight items), and physical symptoms (seven items). The score is calculated by the simple sum of the responses to each question. The higher the score, the greater the perception of vocal symptoms and their consequences in daily life owing to a voice problem. The VoiSS presents maximum (100\%) sensitivity and specificity to separate dysphonic from vocally healthy individuals ${ }^{(8,9)}$. The List of Vocal Signs and Symptoms (LVSS) ${ }^{(10,11)}$ is another tool used to assess the presence of vocal signs and symptoms. It is applied to differentiate vocally healthy individuals from individuals with vocal complaints; it considers work-related activities.

Vocal tract discomforts, such as throat pain and soreness, are commonly observed in teachers ${ }^{(12)}$. Studies have described that the most frequent vocal signs and symptoms in teachers bear little relation to the quality of voice produced and are more frequently associated with the physical sensations inherent in vocal production, such as fatigue, effort, and discomfort ${ }^{(10,11)}$. Voice disorders, when associated with excessive exertion, may be related to muscle tension dysphonia (MTD), the effort may be apparent throughout the vocal tract, involving the entire musculature, both intrinsically and extrinsically.

To investigate vocal discomfort, Mathieson et al. ${ }^{(13)}$ developed the Vocal Tract Discomfort Scale (VTD scale), a self-rating instrument that seeks to identify the sensory perception of discomfort in the vocal tract using eight qualitative descriptors: burning, tight, dry, aching, tickling, sore, irritable, and lump in the throat, according to the frequency and severity of the symptoms. In its validated Brazilian version, Rodrigues et al. ${ }^{(12)}$ used this instrument to assess teachers with and without vocal complaints and found more discomfort in the vocal tract for both frequency and severity in teachers with vocal complaints, compared with those of teachers without complaints.

Therefore, the objective of this study was to evaluate the vocal tract discomfort reported by teachers, comparing their vocal self-assessment at three different times: before teaching, after four hours of teaching, and after eight hours of teaching.

\section{METHODS}

The present survey was approved by the Research Ethics Committee of the aforementioned Institution under Ethical Appreciation Certificate no. 31810814.9.0000.5501, opinion no. 687.202. All participants signed an Informed Consent Form (ICF), thus agreeing with the realization of this study and dissemination of its results.

The study sample was composed of 50 pre- and elementary school teachers (42 women and eight men) with mean age of 39 years. Inclusion criteria comprised being a teacher, active in the teaching activity, over 18 years of age, and teach two daily shifts of four hours each, completing the workload of 40 hours a week. Exclusion criteria were as follows: teachers who were on vacation, medical leave, or absent from teaching, who had previously undergone speech-language therapy, and who presented neurological, psychological and/or psychiatric alterations that prevent them from participating in the study; hormonal problems, use of medication, and smoking were disregarded.

The participating teachers were divided into two groups according to the cutoff value for screening of the Voice Symptom Scale (VoiSS) ${ }^{(7,8)}$. Individuals with total VoiSS score $\geq 16$ points were allocated to the Vocal Risk Group (VRG) (26 teachers), whereas those with total VoiSS score $<16$ points were allocated to the Vocally Healthy Group (VHG) (24 teachers). The List of Vocal Signs and Symptoms (LVSS) ${ }^{(10,11)}$ was applied to all participants to identify the number of vocal symptoms in each group. Both the VoiSS and the LVSS were used only once at the "before teaching" moment (BT). The Vocal Tract Discomfort Scale (VTD scale) ${ }^{(12,13)}$ and the vocal self-assessment were applied at three distinct times: before teaching (BT) and after four (4HT) and eight (8HT) hours of teaching on the same working day. The evaluation days were chosen randomly according to the availability of the school, but all the assessments with each teacher were conducted on the same day.

The VoiSS ${ }^{(7,8)}$ is composed of 30 items divided into three domains (subscales): impairment (15 items), emotional response (eight items), and physical symptoms (seven items), and it is used to identify vocal symptoms and voice change. The protocol includes a 5-point frequency response scale: 
$0=$ never, $1=$ occasionally, $2=$ some of the time, $3=$ most of the time, and $5=$ always. It presents a partial score for each of the three subscales and a total score which is the sum of these three scores. The total score is calculated by the simple sum of the responses to each question. The higher the score, the greater the perception of vocal symptoms and their consequences in daily life owing to a voice problem. The VoiSS has a cutoff value of 16 points of the total score, with $100 \%$ sensitivity and $100 \%$ specificity to separate dysphonic individuals from vocally healthy individuals ${ }^{(8,9)}$. In the present study, this scale was utilized to sort teachers at vocal risk and vocally healthy teachers.

The LVSS ${ }^{(10,11)}$ investigates 14 vocal signs and symptoms, namely, 1- hoarseness, 2- voice tires or changes quality after short use, 3- trouble speaking or singing softly, 4- difficulty projecting voice, 5- loss of singing range, 6- discomfort while using voice, 7- a monotone voice, 8- effort to talk, 9- chronic throat dryness, 10- chronic throat soreness, 11- frequent throat clearing, 12- bitter or acid taste, 13- swallowing difficulties, and 14- a wobbly or shaky voice. This instrument provides the number of vocal symptoms self-reported by the individual, scoring one point for each present symptom and showing whether this symptom is work-related or not; it is used to identify the number of signs and symptoms in each group.

The VTD scale ${ }^{(12,13)}$ assesses the sensory perception using eight qualitative descriptors: 1- burning, 2- tight, 3- dry, 4- aching, 5- tickling, 6- sore, 7- irritable, and 8- lump in the throat, according to the frequency and severity of symptoms, in a seven-point scale from 0 (never/none) to 6 (always/extreme), evidencing the vocal tract discomfort at each of the three assessment times.

The vocal self-assessment was conducted by means of the following question: "What do you think of your voice?". The teachers used a five-point scale to give their responses, in which $0=$ an excellent voice, $1=$ a very good voice, $2=$ a good voice, $3=$ a reasonable voice, and $4=a$ bad voice, thus evidencing the teachers' self-perception of their voice in each of the three evaluation moments.

The VTD scale ${ }^{(12,13)}$ and the vocal self-assessment were applied at the three evaluation times of this study: before teaching (BT) and after four (4HT) and eight (8HT) hours of teaching. The participating teachers reported the frequency and severity of discomfort in the vocal tract and also what they thought of their voices at that time; later comparison was performed to identify whether the self-reported discomfort correlated to the vocal self-assessment.

Because the data of this study are quantitative and continuous and the sample included more than 30 individuals, statistical parametric tests were used to guarantee distribution normality, according to the Central Limit Theorem. Significance level of $0.05(5 \%)$ was adopted for all statistical analyses. The ANOVA test was used for comparison between groups, whereas the ANOVA test with repeated measures was applied to compare the assessment times.

\section{RESULTS}

Based on the List Vocal Signs and Symptoms (LVSS), teachers at vocal risk presented a larger number of total and work-related vocal symptoms compared with that of vocally healthy teachers, as shown in Table 1.

Table 2 shows that the teachers reported greater frequency and severity of vocal tract discomfort after four and eight hours of teaching. Teachers at vocal risk reported almost double the frequency and severity of vocal tract discomfort, contrary to what was observed for vocally healthy teachers.

Comparison of frequency and severity of vocal tract discomfort between vocally healthy teachers and teachers at vocal risk revealed that the latter presented double the symptoms and that such symptoms increased after four and eight hours of teaching, as shown in Table 3.

Table 4 shows that the teachers presented worse vocal self-assessment after four and eight hours of teaching. Teachers at vocal risk presented even worse vocal self-assessment throughout the teaching working day, contrary to what was found for vocally healthy teachers.

Teachers at vocal risk presented worse vocal self-assessment compared with that of vocally healthy teachers, who presented more positive self-assessments throughout the teaching working day, as shown in Table 5.

Table 1. Vocal signs and symptoms in vocally healthy teachers and in teachers at vocal risk

\begin{tabular}{|c|c|c|c|c|c|c|}
\hline $\begin{array}{c}\text { List of Vocal Signs and } \\
\text { Symptoms - LVSS }\end{array}$ & $\mathrm{N}$ & Mean & Median & SD & $\mathrm{Cl}$ & $p$ value \\
\hline \multicolumn{7}{|l|}{ Total } \\
\hline VHG & 24 & 0.56 & 0.25 & 0.74 & 0.30 & \multirow{2}{*}{$<0.001^{*}$} \\
\hline VRG & 26 & 1.60 & 1.50 & 0.98 & 0.38 & \\
\hline \multicolumn{7}{|l|}{ Work-related } \\
\hline VHG & 24 & 0.79 & 0.38 & 0.86 & 0.34 & \multirow{2}{*}{$<0.001^{*}$} \\
\hline VRG & 26 & 2.49 & 2.56 & 1.22 & 0.47 & \\
\hline
\end{tabular}

*Statistically significant values $(p \leq 0.05)$ - ANOVA test

Caption: $\mathrm{VHG}=$ Vocally healthy group; $\mathrm{VRG}=$ Vocal risk group; $\mathrm{N}=$ number of individuals; $\mathrm{SD}=$ Standard deviation; $\mathrm{Cl}=\mathrm{Confidence} \mathrm{interval}$ 
Table 2. Assessment times for vocally healthy teachers and for teachers at vocal risk according to their responses to the frequency and severity in the domains of the VTD scale

\begin{tabular}{|c|c|c|c|c|c|c|}
\hline VTD scale & $\mathrm{N}$ & Mean & Median & SD & $\mathrm{Cl}$ & $p$ value \\
\hline \multicolumn{7}{|l|}{ Frequency } \\
\hline \multicolumn{7}{|l|}{ VHG } \\
\hline BT & 24 & 0.56 & 0.25 & 0.74 & 0.30 & \multirow{2}{*}{0.132} \\
\hline $8 \mathrm{HT}$ & 24 & 0.79 & 0.31 & 0.98 & 0.39 & \\
\hline \multicolumn{7}{|l|}{ VRG } \\
\hline $8 \mathrm{HT}$ & 26 & 2.95 & 2.94 & 1.21 & 0.46 & $<0.001$ \\
\hline \multicolumn{7}{|l|}{ Total } \\
\hline BT & 50 & 1.10 & 1.00 & 1.01 & 0.28 & \multirow{3}{*}{$<0.001^{*}$} \\
\hline $4 \mathrm{HT}$ & 50 & 1.68 & 1.56 & 1.36 & 0.38 & \\
\hline $8 \mathrm{HT}$ & 50 & 1.91 & 2.00 & 1.55 & 0.43 & \\
\hline \multicolumn{7}{|l|}{ Severity } \\
\hline $8 \mathrm{HT}$ & 24 & 0.76 & 0.38 & 0.94 & 0.38 & 0.431 \\
\hline \multicolumn{7}{|l|}{ VRG } \\
\hline BT & 26 & 1.79 & 1.81 & 1.11 & 0.43 & \multirow{3}{*}{$<0.001$} \\
\hline $4 \mathrm{HT}$ & 26 & 2.52 & 2.38 & 1.12 & 0.43 & \\
\hline $8 \mathrm{HT}$ & 26 & 3.12 & 2.94 & 1.22 & 0.47 & \\
\hline \multicolumn{7}{|l|}{ Total } \\
\hline BT & 50 & 1.19 & 1.06 & 1.12 & 0.31 & \multirow{3}{*}{$<0.001^{*}$} \\
\hline $4 \mathrm{HT}$ & 50 & 1.66 & 1.69 & 1.32 & 0.37 & \\
\hline $8 \mathrm{HT}$ & 50 & 1.98 & 2.06 & 1.61 & 0.45 & \\
\hline
\end{tabular}

*Statistically significant values $(\mathrm{p} \leq 0.05)$ - ANOVA test with repeated measures

Caption: VTD scale = Vocal tract discomfort scale; VHG = Vocally healthy group; VRG = Vocal risk group; $\mathrm{N}=$ number of individuals; $\mathrm{SD}=\mathrm{Standard}$ deviation; $\mathrm{Cl}=$ Confidence interval; Assessment times: $\mathrm{BT}=$ before teaching; $4 \mathrm{HT}=$ after four hours of teaching; $8 \mathrm{HT}=$ after eight hours of teaching. $\mathrm{p}$ values according to the studied groups for the VTD scale frequency comparing the moments in pairs: VRG: BT $\times 4 \mathrm{HT}=0.001^{*}$; BT $\times 8 \mathrm{HT}=0.001^{*}$; $4 \mathrm{HT} \times 8 \mathrm{HT}=0.001^{*}$; Total sample: $\mathrm{BT} \times 4 \mathrm{HT}=0.001^{*}$; $\mathrm{BT} \times 8 \mathrm{HT}=0.001^{*} ; 4 \mathrm{HT} \times 8 \mathrm{HT}=0.003^{*}$. $\mathrm{p}$ values according to the studied groups for the VTD scale severity comparing the moments in pairs: VRG: $\mathrm{BT} \times 4 \mathrm{HT}=0.001^{*}$; $\mathrm{BT} \times 8 \mathrm{HT}=0.001^{*} ; 4 \mathrm{HT} \times 8 \mathrm{HT}=0.001^{*}$; Total sample: $\mathrm{BT} \times 4 \mathrm{HT}=0.001^{*}$; $\mathrm{BT} \times 8 \mathrm{HT}=0.001^{*} ; 4 \mathrm{HT} \times 8 \mathrm{HT}=0.001^{*}$

Table 3. Comparison between vocally healthy teachers and teachers at vocal risk according to the frequency and severity in the domains of the VTD scale at the three different assessment times

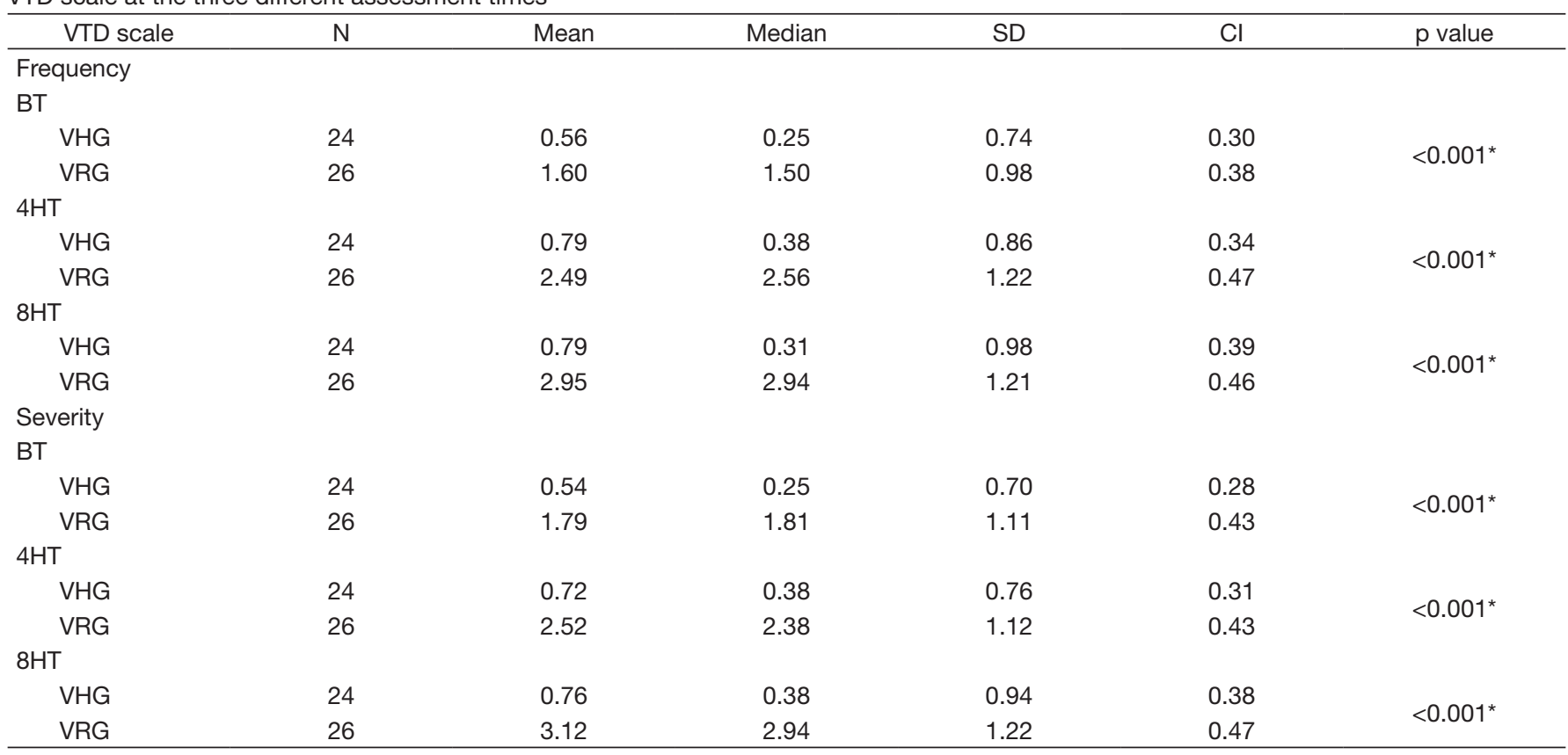

*Statistically significant values $(\mathrm{p} \leq 0.05)$ - ANOVA test

Caption: VTD scale = Vocal tract discomfort scale; VHG = Vocally healthy group; VRG = Vocal risk group; $\mathrm{N}=$ number of individuals; $\mathrm{SD}=\mathrm{Standard}$ deviation; $\mathrm{Cl}$ = Confidence interval; Assessment times: $\mathrm{BT}=$ before teaching; $4 \mathrm{HT}$ = after four hours of teaching; $8 \mathrm{HT}=$ after eight hours of teaching 
Table 4. Assessment times for vocally healthy teachers and for teachers at vocal risk according to their vocal self-assessment

\begin{tabular}{|c|c|c|c|c|c|c|}
\hline $\begin{array}{c}\text { Vocal } \\
\text { self-assessment }\end{array}$ & $\mathrm{N}$ & Mean & Median & SD & $\mathrm{Cl}$ & $p$ value \\
\hline \multicolumn{7}{|l|}{ VHG } \\
\hline $\mathrm{BT}$ & 24 & 0.67 & 1.00 & 0.64 & 0.25 & \multirow{3}{*}{0.007} \\
\hline $4 \mathrm{HT}$ & 24 & 0.96 & 1.00 & 0.75 & 0.30 & \\
\hline $8 \mathrm{HT}$ & 24 & 0.96 & 1.00 & 0.75 & 0.30 & \\
\hline \multicolumn{7}{|l|}{ VRG } \\
\hline BT & 26 & 2.00 & 2.00 & 0.80 & 0.31 & \multirow{3}{*}{$<0.001^{*}$} \\
\hline $4 \mathrm{HT}$ & 26 & 2.42 & 2.50 & 0.70 & 0.27 & \\
\hline $8 \mathrm{HT}$ & 26 & 3.00 & 3.00 & 0.85 & 0.33 & \\
\hline \multicolumn{7}{|l|}{ Total } \\
\hline BT & 50 & 1.36 & 1.00 & 0.98 & 0.27 & \multirow{3}{*}{$<0.001^{*}$} \\
\hline $4 \mathrm{HT}$ & 50 & 1.72 & 2.00 & 1.03 & 0.29 & \\
\hline $8 \mathrm{HT}$ & 50 & 2.02 & 2.00 & 1.30 & 0.36 & \\
\hline
\end{tabular}

*Statistically significant values ( $\mathrm{p} \leq 0.05)$ - ANOVA test with repeated measures

Caption: VHG = Vocally healthy group; VRG = Vocal risk group; $\mathrm{N}=$ number of individuals; $\mathrm{SD}=\mathrm{Standard}$ deviation; $\mathrm{Cl}=\mathrm{Confidence}$ interval; Assessment times: $\mathrm{BT}$ = before teaching; $4 \mathrm{HT}=$ after four hours of teaching; $8 \mathrm{HT}=$ after eight hours of teaching. $\mathrm{p}$ values according to the studied groups for the vocal self-assessment

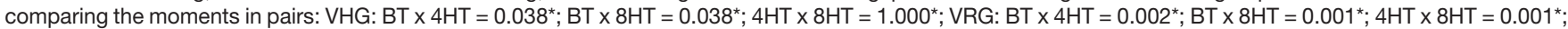

Total sample: BT $\times 4 \mathrm{HT}=0.001^{*}$; BT $\times 8 \mathrm{HT}=0.001^{*} ; 4 \mathrm{HT} \times 8 \mathrm{HT}=0.001^{*}$

Table 5. Comparison between vocally healthy teachers and teachers at vocal risk according to their vocal self-assessment at the three different assessment times

\begin{tabular}{|c|c|c|c|c|c|c|}
\hline $\begin{array}{c}\text { Vocal } \\
\text { self-assessment }\end{array}$ & $N$ & Mean & Median & SD & $\mathrm{Cl}$ & $p$ value \\
\hline \multicolumn{7}{|l|}{ BT } \\
\hline VHG & 24 & 0.67 & 1.00 & 0.64 & 0.25 & \multirow{2}{*}{$<0.001^{\star}$} \\
\hline VRG & 26 & 2.00 & 2.00 & 0.80 & 0.31 & \\
\hline \multicolumn{7}{|l|}{$4 \mathrm{HT}$} \\
\hline VHG & 24 & 0.96 & 1.00 & 0.75 & 0.30 & \multirow{2}{*}{$<0.001$} \\
\hline VRG & 26 & 2.42 & 2.50 & 0.70 & 0.27 & \\
\hline \multicolumn{7}{|l|}{$8 \mathrm{HT}$} \\
\hline VHG & 24 & 0.96 & 1.00 & 0.75 & 0.30 & \multirow{2}{*}{$<0.001$} \\
\hline VRG & 26 & 3.00 & 3.00 & 0.85 & 0.33 & \\
\hline
\end{tabular}

*Statistically significant values $(\mathrm{p} \leq 0.05)$ - ANOVA test

Caption: VHG = Vocally healthy group; VRG = Vocal risk group; $\mathrm{N}=$ number of individuals; $\mathrm{SD}=\mathrm{Standard}$ deviation; $\mathrm{Cl}=\mathrm{Confidence}$ interval; Assessment times:

$\mathrm{BT}=$ before teaching; $4 \mathrm{HT}=$ after four hours of teaching; $8 \mathrm{HT}=$ after eight hours of teaching

\section{DISCUSSION}

Teachers usually use the voice with high intensity and report hoarseness, fatigue, and burning in the throat after a work shift ${ }^{(14)}$. In addition, they face situations of anxiety, stress, and anguish, as well as extensive working hours ${ }^{(4)}$. Considering the situation endured by teachers in their daily working life, this study aimed to investigate the vocal tract discomfort (VTD) in vocally healthy teachers and in teachers at vocal risk by comparing their vocal self-assessment at three different times: before teaching (BT) and after four (4HT) and eight (8HT) hours of teaching. The List of Vocal Signs and Symptoms (LVSS) (Table 1) was used to assess the number of total and work-related vocal signs and symptoms in each group. The results showed that teachers at vocal risk presented a larger number of work-related vocal signs and symptoms compared with that of vocally healthy teachers, corroborating the findings of another study ${ }^{(15)}$ conducted with teachers with vocal complaints who sought voice treatment, teachers with vocal complaints who did not seek voice treatment, and vocally healthy teachers, which verified that teachers with vocal complaints generally present higher mean of vocal signs and symptoms than healthy teachers.

Teachers at vocal risk presented greater frequency and severity of VTD at the end of a day's work, that is, after eight hours of teaching (Table 2). The worsening of discomfort may be related to occupational hazards associated with the work environment and organization, which may harm vocal health ${ }^{(16)}$. It is also known that teachers are professionals who present a chance to develop moderate or severe voice problems, depending on their work environment and teaching hours ${ }^{(2)}$. Vocally healthy teachers presented little or no VTD, which was also observed in a Belgian study conducted in partnership with Brazilian authors that verified the occurrence of VTD in a population without vocal disorders ${ }^{(17)}$, but the teachers at vocal risk showed higher frequency and severity of VTD. These results corroborate those of a Brazilian study that verified VTD in patients with different vocal changes, and the discomfort in this population with vocal alteration was also high $^{(18)}$. 
Teachers at vocal risk, when compared with vocally healthy teachers, showed greater frequency and severity of VTD (Table 3), which is in agreement with data reported in other studies, in which teachers with vocal alteration who present greater $\operatorname{VTD}^{(19)}$ and male teachers with vocal complaints, assessed after a day's work, presented greater symptoms of vocal fatigue compared with those of teachers without vocal complaints, in addition to increased symptoms throughout the working hours in the group of teachers with vocal complaint ${ }^{(6)}$.

Regarding the vocal self-assessment, Table 4 shows that vocally healthy teachers presented more positive self-assessments at all evaluation times, contrary to teachers at vocal risk, who had more negative self-assessments, which increased after four and eight hours of teaching; it is worth noting that vocal self-assessment tends to be more positive in individuals without voice disorders and vocal complaints ${ }^{(8)}$.

Correlation was observed between vocal self-assessment and the VTD scale, with vocally healthy teachers reporting little or no VTD and presenting more positive vocal self-assessments, whereas teachers at vocal risk presented more negative self-assessments, associated with increased VTD, which suggests that the presence of discomfort influences the vocal self-assessment. This correlation corroborates the data by Rodrigues et al. ${ }^{(12)}$, who found greater VTD reported by teachers with worse vocal self-assessment. This fact indicates that there is a correlation between the perception of a worse voice and greater VTD, possibly due to the greater vocal effort during teaching, which increases the sensation of discomfort.

Teachers at vocal risk presented poor vocal self-assessment (Table 5), which worsened throughout the teaching hours as the severity and frequency of VTD increased. In contrast, vocally healthy teachers presented positive vocal self-assessment, in addition to reporting little or no VTD, evidencing that the individual's perception of voice is associated with the frequency and severity that the vocal symptoms appear ${ }^{(20)}$.

The data of the present study reinforce the fact that teachers who teach with symptoms of VTD present additional risk to develop vocal alterations, indicating use of the voice with increased effort and without adequate techniques ${ }^{(15)}$. Therefore, educational measures on the use of the voice should be included in the professional training of teachers, which would provide speech-language pathologists with data to identify which teachers need assistance and should thus be referred to medical and speech-language therapy.

\section{CONCLUSION}

Teachers at vocal risk present worse vocal self-assessment and increased vocal tract discomfort after four and eight hours of teaching on the same working day, which may indicate the development of dysphonia.

These results can be used to monitor teachers and assist them with identifying immediate negative impacts after a day's work, contributing to the selection of teachers to be referred to medical and speech-language pathology assessment.

\section{REFERENCES}

1. Freitas SV. Disfonia em professoras do primeiro ciclo do ensino básico. Arq Med. 2006;20(5-6):145-52.

2. Behlau M. Vozes preferidas: considerações sobre opções vocais nas profissões. Fono Atual. 2001;16(4):10-4.

3. Choi-Cardim K, Behlau M, Zambon F. Sintomas vocais e perfil de professores em um programa de saúde vocal. Rev CEFAC. 2010;12(5):811-9. http:// dx.doi.org/10.1590/S1516-18462010005000075.

4. Alves LA, Robazzi MLCC, Marziale MHP, Felippe ACN, Romano CC. Alterações da saúde e a voz do professor, uma questão de saúde do trabalhador. Rev Lat Am Enfermagem. 2009;17(4):566-72. PMid:19820866. http://dx.doi.org/10.1590/S0104-11692009000400020.

5. Zambon FC. Sintomas vocais, hábitos e condições de trabalho dos professores atendidos no SINPRO-SP [monografia]. São Paulo: Centro de Estudos da Voz; 2005.

6. Laukkanen A-M, Kankare E. Vocal loading-related changes in male teachers voices investigated before and after a working day. Folia Phoniatr Logop. 2006;58(4):229-39. PMid:16825776. http://dx.doi.org/10.1159/000093180.

7. Moreti F, Zambon F, Oliveira G, Behlau M. Cross-cultural adaptation of the Brazilian version of the Voice Symptom Scale: VoiSS. J Soc Bras Fonoaudiol. 2011;23(4):398-400. PMid:22231064. http://dx.doi.org/10.1590/ S2179-64912011000400018.

8. Moreti F, Zambon F, Oliveira G, Behlau M. Cross-cultural adaptation, validation, and cutoff values of the Brazilian version of the Voice Symptom Scale-VoiSS. J Voice. 2014;28(4):458-68. PMid:24560004. http://dx.doi. org/10.1016/j.jvoice.2013.11.009.

9. Behlau M, Madazio G, Moreti F, Oliveira G, Santos LM, Paulinelli BR, et al. Efficiency and cutoff values of self-assessment instruments on the impact of a voice problem. J Voice. 2016;30(4):506.e9-18. PMid:26168902. http:// dx.doi.org/10.1016/j.jvoice.2015.05.022.

10. Roy N, Merrill RM, Thibeault S, Gray SD, Smith EM. Voice disorders in teachers and the general population: effects on work performance, attendance, and future career choices. J Speech Lang Hear Res. 2004;47(3):542-51. PMid:15212567. http://dx.doi.org/10.1044/1092-4388(2004/042).

11. Behlau M, Zambon F, Guerrieri AC, Roy N. Epidemiology of voice disorders in teachers and nonteachers in Brazil: Prevalence and adverse effects. J Voice. 2012;26(5):665.e9-18. PMid:22516316. http://dx.doi.org/10.1016/j. jvoice.2011.09.010.

12. Rodrigues G, Zambon F, Mathieson L, Behlau M. Vocal Tract discomfort in teachers: its relationship to self-reported voice disorders. J Voice. 2013;27(4):473-80. PMid:23528674. http://dx.doi.org/10.1016/j. jvoice.2013.01.005.

13. Mathieson L, Hirani SP, Epstein R, Baken RJ, Wood G, Rubin JS. Laryngeal manual therapy: a preliminary study to examine its treatment effects in the management of muscle tension dysphonia. J Voice. 2009;23(3):353-66. PMid:18036777. http://dx.doi.org/10.1016/j.jvoice.2007.10.002.

14. Libardi A, Goncalves GO, Vieira TP, Silverio KC, Rossi D, Penteado RZ. $\mathrm{O}$ ruído em sala de aula e a percepção dos professores de uma escola de ensino fundamental de Piracicaba. Distúrb Comum. 2006;18(2):167-78.

15. Zambon F, Moreti F, Behlau M. Coping strategies in teachers with vocal complaint. J Voice. 2014;28(3):341-8. PMid:24495425. http://dx.doi. org/10.1016/j.jvoice.2013.11.008.

16. Servilha EAM, Ruela IS. Riscos ocupacionais à saúde e voz de professores: especificidades das unidades de rede municipal de ensino. Rev CEFAC. 2010;12(1):109-14. http://dx.doi.org/10.1590/S1516-18462009005000061.

17. Luyten A, Bruneel L, Meerschman I, D'haeseleer E, Behlau M, Coffé $\mathrm{C}$, et al. Prevalence of vocal tract discomfort in the flemish population without self-perceived voice disorders. J Voice. 2016;30(3):308-14 PMid:26025618. http://dx.doi.org/10.1016/j.jvoice.2015.04.017.

18. Lopes LW, Cabral GF, Almeida AAF. Vocal tract discomfort symptoms in patients with different voice disorders. J Voice. 2015;29(3):317-23. PMid:25499523. http://dx.doi.org/10.1016/j.jvoice.2014.07.013. 
19. Chen SH, Chiang SC, Chung YM, Hsiao LC, Hsiao TY. Risk factors and effects of voice problems for teachers. J Voice. 2010;24(2):183-90, quiz 191-2. PMid:19481416. http://dx.doi.org/10.1016/j.jvoice.2008.07.008.

20. Lyberg Åhlander V, Rydell R, Löfqvist A. How do teachers with self-reported voice problems differ from their peers with self-reported voice health? J Voice. 2012;26(4):e149-61. PMid:21889297. http://dx.doi.org/10.1016/j. jvoice.2011.06.005.

\section{Author contributions}

ACA was responsible for the collection and analysis of data and writing and revision of the manuscript; FZ and FM were responsible for the study design, analysis of data, and revision of the manuscript; $M B$ was responsible for the study design, analysis of data, and final revision of the manuscript. 